\title{
APSKATI
}

https://doi.org/10.22364/adz.57.15

\section{AKADĒMISKĀ MŪŽORGANIZĀCIJA FRATERNITAS RUSTICANA SIMTGADĒ}

\section{Fr!R! F!Elmārs Pelkaus}

2021. gada novembra sākumā savu 100. gadskārtu svin viena no Latvijas brīvvalsts sākumgados dibinātajām studentu organizācijām - Fraternitas Rusticana. Par šīs organizācijas pirmo 75 gadu darbību pārskats sniegts Akadēmiskās Dzīves 39. numurā'. Gandrīz katrā no šì izdevuma sekojošiem numuriem hronikas sadaḷā sniegtas ziṇas par Fraternitas Rusticana (turpmāk tekstā - Fr!R!) darbību attiecīgajā mācību gadā.

Fr!R! 75. gadskārtai veltīto rakstu šo rindiņu autors beidza ar vārdiem: "Atjaunotā Fr!R! pagaidām ir grūti pielīdzināma pirmskara Zemnieku Brālībai. Tomēr laiku maiṇā par nokalstošo vērtētā ozolā kāds zars vēl spilgti un spītīgi zalı.”. Šos vārdus visnotal̦ varētu attiecināt uz organizāciju arī pašlaik, kaut gan nepielūdzamais mūžības vējš atrāvis no ozola dažu labu košu lapu. Šo zaudējumu organizatoriskā izpausme ir bijusi Globālā prezidija (darbības pēdējos gados koordinēja Fr!R! aktivitātes ārpus Latvijas) funkcionēšanas izbeigšana 2009. gada pavasarī. Vienlaikus jāatzīmē, ka krietni ciešākas kḷuvušas saites starp rustikāṇiem Latvijā un rustikāṇu kopu ASV, kas

\footnotetext{
1 Pelkaus, Elmārs (1999/2000) Akadēmiskās mūža organizācijas Fraternitas Rusticana 75 gadu darbība. Akadēmiskā Dzīve, 39, 93-96.
}

noris ar devīzi "Kaut šķirti, tomēr nešķirami”." Pamatojoties uz 1999. gada 17. aprīlī noslēgto sadraudzības līgumu, turpina attīstīties Fr!R! draudzīgās attiecības ar akadēmiskajām vienībām, tiek pārvarēta Latvijas brīvvalsts laikam raksturīgā nepamatotā atsvešinātība no studenšu un studentu korporācijām - apliecinājums tam ir ikgadējais akadēmisko mūžorganizāciju gājiens no Latvijas Universitātes uz Rīgas Brāļu kapiem. Ir pamats domāt, ka pēc pandēmijas pierimšanas šis attiecības uzplauks vēl krāšnāk.

Sekojot sava goda filistra (G!F!) Kārḷa Ulmaņa Draudzīgajam aicinājumam, Fr!R! šī gadsimta sākumā ik gadus dāvināja grāmatas skolām un bērnunamiem no trimdas rustikāṇu sarūpētās un uz Latviju pārvestās, par Fr!R! F!Pētera Austriṇa Piemiñas bibliotēku nosauktās grāmatu krātuves rezerves fonda. 2006. gadā Fr!R! nodeva šo - vairākus tūkstošus grāmatu aptverošo - bibliotēku valsts īpašumā, glabāšanā Latvijas Valsts arhīvā. Tieši tāpat tika nodots arī lasītavas iekārtošanai paredzētais mēbel̦u komplekts.

${ }^{2}$ Sk. informāciju par Latvijas un ASV rustikāņu tikšanos 2018. gada 6. jūlijā (Akadēmiskā Dzīve [2019/2020], 55, 143). Šis tikšanās organizēšanā ipašsi nopelni bija Fr!R! filistram (F!) Guntim Ulmanim. 


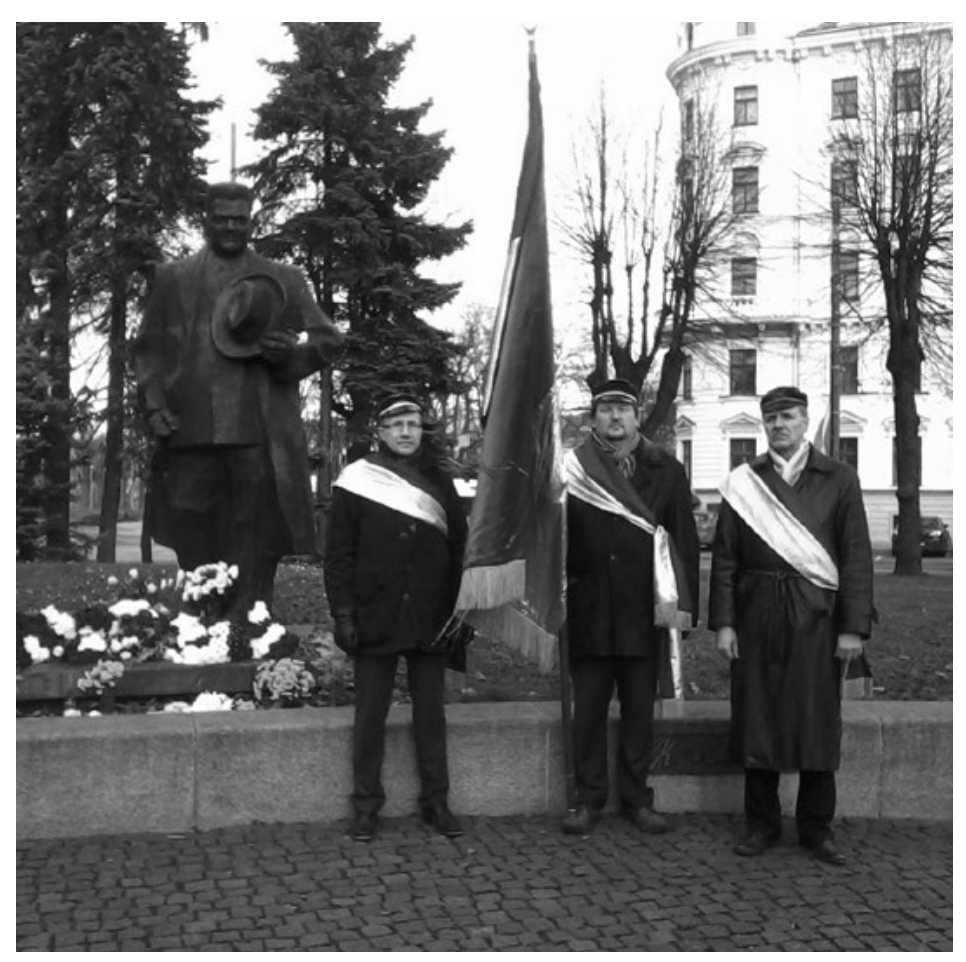

\section{1. attēls. Ziedu nolikšana pie Fr!R! goda filistra Kārḷa Ulmaṇa pieminekḷa Rīgā} 2013. gada 18. novembrī

Katru gadu pēc svinīgā gājiena uz Brāḷu kapiem rustikāṇi ir devušies pie G!F!K. Ulmaņa pieminekḷa Rīgas centrā, lai godinātu visu laiku diženākā latviešu valstsvīra piemiņu.

Organizācijas pārstāvji piedalïjušies K. Ulmaṇa pieminekḷu atklāšanā viṇa dzimtajās mājās Pikšās un Valkā. 2014. gadā 15. novembrī Valkā atklātā pieminekḷa tapšanā rustikāņi piedalìjušies arī ar nozīmīgu naudas ziedojumu.

Šì gada 11. aprīlī Fr!R! attālināti (pandēmijas noteikto ierobežojumu dēḷ) pieminēja 85. gadskārtu, kopš K. Ulmanis uzņēmies Valsts prezidenta pienākumus.

Šajā sakarā vērts pieminēt akadēmiḳa Jāṇa Stradiṇa runu Jelgavas Latviešu biedrības 130 gadu dibināšanas sarīkojumā 2010. gada 12. jūnijā, kurā viņš teica, ka "jāatzīst gan K. Ulmaņa noteicošā, izšḳirīgā loma 1918. gada 18. novembrī, viņa spēja uzn,emties atbildību par jauno valsti kritiskajā brīdī - un šajā ziṇā [..] viṇa loma bija izšḳirīgāka nekā Jānim Čakstem .. Bet kas ir vēl būtiskāk - K. Ulmanis centās latviskot Latviju, dot latviešu valodai tās tiesības, latviešu uzṇēmējiem vadošo vietu, ieviešot latvisko garu visās dzīves jomās, varbūt pat pārspīlēti apkarojot vācisko, pat eiropisko. Es gribu uzsvērt, ka diez vai latviešu nācija 50 nebrīves gados būtu iespējusi saglabāt nacionālo latvisko garu, ja nebūtu bijuši K. Ulmaņa valdī̌̌anas 6 gadi ar uzsvērto latviskumu, ja K. Ulmanis nebūtu devis lādinu turpmākajiem nebrīves gadiem. Man liekas, pašapziņa, pašvērtības apzināšanās ir pats izšķirīgais, ko K. Ulmanis deva latviešu tautai, un tas palīdzēja tai saglabāties un palīdz arī šodien"”.

J. Stradiņš raksturo K. Ulmani kā "lepnu zemgalieti ar ticību "mūžīgai Latvijai, nacionālai, daiḷai, varenai"'"4, taču diez vai var piekrist viña apgalvojumam, ka piemineklī Rīgā valstsvīrs attēlots kā piezemināts, piedošanu

\footnotetext{
${ }^{3}$ Stradiņš, Jānis (2010/2011). Jelgavas latviskā un eiropeiskā identitāte. Akadēmiskā Dzīve, 47, 123.

4 Turpat.
} 
lūdzošs. Rustikānu ieskatā, K. Ulmanim nav, par ko lūgt piedošanu - katrā zin̄ā ne par tiem vārdiem, kas rakstīti pieminekḷa pakājē. Jā, 1934. gada 15. maija apvērsums bija pretlikumīgs - bet pretlikumīga bija arī Lielā franču revolūcija, kas lika pamatus mūsdienu modernajai Eiropai, pretlikumīga bija 1917. gada Februāra revolūcija, kas nesa brīvību Krievijas tautām (un šo iespēju Krievija neprata izmantot), tālaika likumiem neatbilstoša bija Latvijas Republikas proklamēšana 1918. gada 18. novembrī, PSRS likumiem neatbilstoša bija Latvijas valstiskuma atjaunošana 1990. gada 4. maijā. Un ar demokrātiju K. Ulmanis bija iepazinies demokrātijas citadelē ASV, kuras savulaik bija pretlikumīgi atšḳēlušās no britu koloniālās impērijas.

Tā dēvētās "15. maija Latvijas" objektīvs izvērtējums nu jau gadsimta ceturksni ir pieejams lasītājiem ${ }^{5}$, mūsu organizācija to pilnībā akceptē. Jāpiebilst, ka šo rindiṇu autoram, savulaik pētot dokumentus Vācijas Federālajā arhīvā (Bundesarchiv Deutschland), izdevās iepazìties ar hronolog̣iski laikam vissenāko direktīvu par minētā perioda nomelnojošo izvērtēšanu. 1941. gada augustā tapušajā Latvijas G̣enerālapgabala pārvaldes darbiniekiem domātajā dokumentā bija uzsvērts, ka K. Ulmanis pieminams tikai kā "angḷu-amerikāṇu žīdiskās plutokrātijas balstītās kliḳes” vadītājs, kurš sazvērnieciski sagrābis varu (nevis ieguvis to "caurspīdīgās" vēlēšanās kā nacionālsociālisti Vācijā) un novedis savu valsti līdz 1940. gada 17. jūnija katastrofai, jo visādi izvairīiies sadarboties ar Reihu.

Savukārt mūsdienās diezgan bieži tiek apgalvots, ka nepretošanās okupācijai nebūtu notikusi, ja būtu pastāvējusi Saeima. Taču Lietuvā un Igaunijā parlamenti pastāvēja, bet notikumu gaita tur bija praktiski analoga. Bet 2007. gada 17. maijā - bez jebkādiem militāriem draudiem Latvijai - Saeima ratificēja robežligumu ar Krieviju, būtībā prettiesiski atsakoties no Abrenes un 6 Abrenes apriņ̧̧a pagastiem. Tā paša gada 29. maijā likumu par robežlīgumu bez iebildumiem parakstija

\footnotetext{
5 Klīve, V.; Karulis, K. (1995) LZS autoritārā režīma laikā (1934-1940). Zunda, A. (sast.) Latvijas Zemnieku savienības vēsture: izcelsme, attīstība, mūsdienas. Rīga : Preses nams, 80-104.
}

F!Guntim Ulmanim amatā sekojošā Valsts prezidente.

Bezcerīgajā situācijā, izvairoties no veltīgas asinsizliešanas, 1940. gadā izdevās nepiel̦aut Latvijas armijas internēšanu un tās kadru masveida iznīcināšanu vēl pirms 1941. gada 14. jūnija. Pēc nepilnīgām ziṇām, komunistiskās okupācijas pirmajā gadā apcietināti vai bez vēsts pazuduši 1086 virsnieki. ${ }^{6}$ Tie bija ārkārtīgi smagi, taču ne katastrofāli zaudējumi. Bet pēc kara sākuma 1941. gada jūnija beigās un jūlija sākumā Latvijas armijas bijušie karavīri, bijušie aizsargu organizācijas dalībnieki un citi savas valsts patrioti pārņēma varu Rīgas priekšpilsētās: Bolderājā, Daugavgrīvā, Bullı,os, Mīlgrāvī un Jaunciemā, sešās apriṇķa pilsētās (Cēsīs, Jelgavā, Talsos, Valkā, Valmierā un Ventspilī), trīspadsmit mazpilsētās (Ainažos, Alūksnē, Apē, Kandavā, Limbažos, Ogrē, Salacgrīiā, Saldū, Siguldā, Slokā, Smiltenē, Strenčos un Valdemārpilī) un daudzos pagastos. ${ }^{7}$ Tā tika kliedēts mìts par Latvijas labprātīgo pievienošanos PSRS - un tas bija nesalīdzināmi efektīvāk nekā verbāls protests pret okupāciju 1940. gada jūnijā, jo tālaika Eiropas politiskajā situācijā šāds protests tikpat paliktu pasaules valstu neievērots.

Svarīgi piebilst, ka cīnā par Latvijas valsts de iure pastāvēšanas turpināšanos izcili nozīmīgas bija ārkārtējās pilnvaras, ko K. Ulmaṇa vadītā valdība 1940. gada 17. maijā pieškīìa sūtnim Lielbritānijā Kārlim Zariņam. Tādējādi Latvijas diplomātiskais dienests pēc okupācijas saglabājās kā vienīgais likumīgais Latvijas Republikas valsts varas pārstāvis un tās viedokḷu paudējs, iespēju robežās pārstāvot Latvijas pilsonu intereses ārvalstīs. ${ }^{8}$

K. Ulmanim pārmet pēdējā radiorunā teiktos vārdus "Es palieku savā vietā, jūs palieciet savās!”. Viṇam pārmet kolaborāciju Baigā

${ }^{6}$ Jēkabsons, Ēriks; Ščerbinskis, Valters (sast.); Latvijas Valsts vēstures arhīvs (1998) Latvijas armijas augstākie virsnieki 1918-1940: Biogräfiskā vārdnìca. Rìga : Nordik, 43.

7 Pelkaus, Elmārs (2004) Cīna un cerība: Partizāni Latvijā 1941. gada vasarā. Rīga : N.I.M.S.

8 Sarkanis, Alberts (sast.) (1999) Dokumenti par Latvijas valsts starptautisko atzǐšanu, neatkarības atjaunošanu un diplomātiskajiem sakariem 1918-1998. Rīga : Nordik, 131-135. 


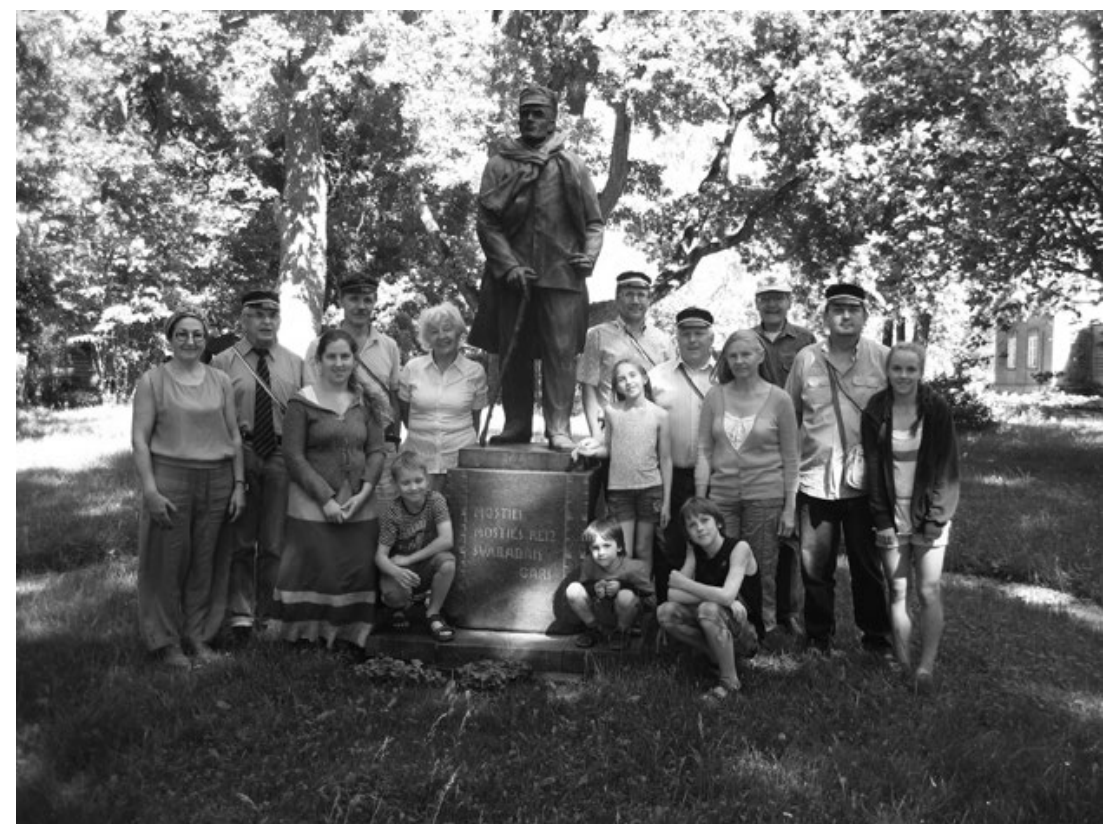

2. attēls. Fr!R! komeršs 2014. gada jūnijā un E. Veidenbauma memoriālā muzeja apmeklējums Kalāčos

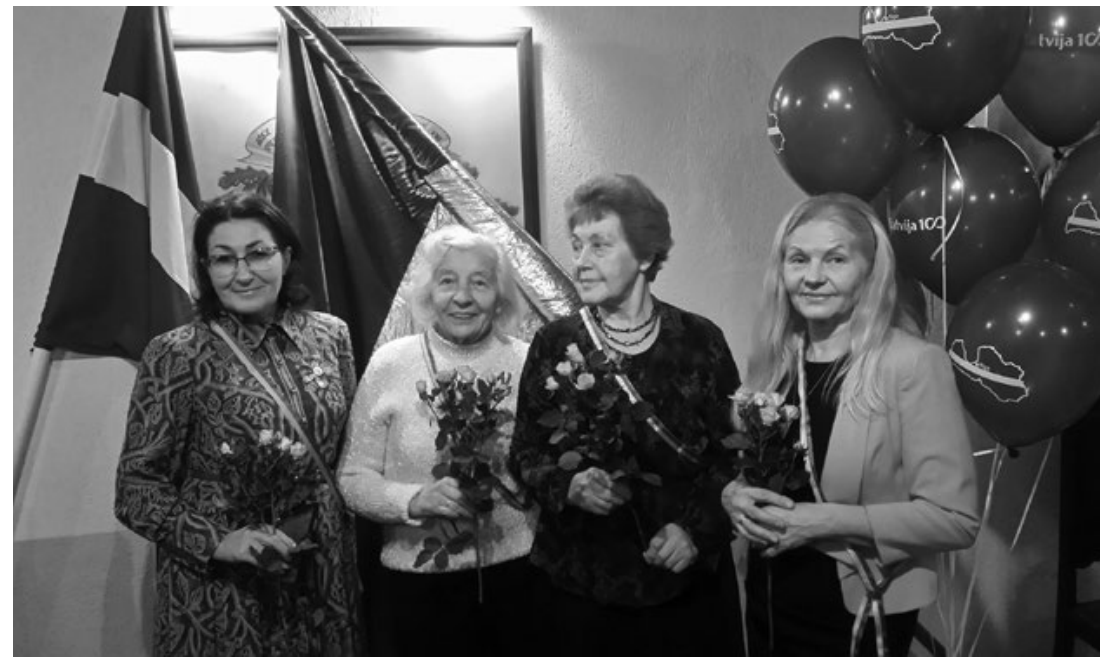

3. attēls. Fr!R! Dāmu komiteja 2018. gada novembrī

gaida jūnijā un jūlijā. $\mathrm{Nu}$ jau mūžǐbas cel̦os aizgājušais Fr!R! F!Aivars Berḳis šajā sakarā rakstīja: "Pārmetumus, ko adresējam Kārlim Ulmanim, ar tādām pašām tiesībām varam adresēt visiem, kas ar savu darbu kalpoja padomju varai .. Manuprāt prezidenta vārdi [..] bija pavēle palikt un censties saglabāt Latviju tādā veidā, kādā katram tas iespējams. Cīnīties ar ieročiem rokās, kā to vēl daudzus gadus pēc kara darīja gandrīz 20 tūkstoši nacionālo partizānu. Pretoties spītējot, kā to darīja Gunārs Astra, Lidija Doroṇina-Lasmane, Broṇislava 


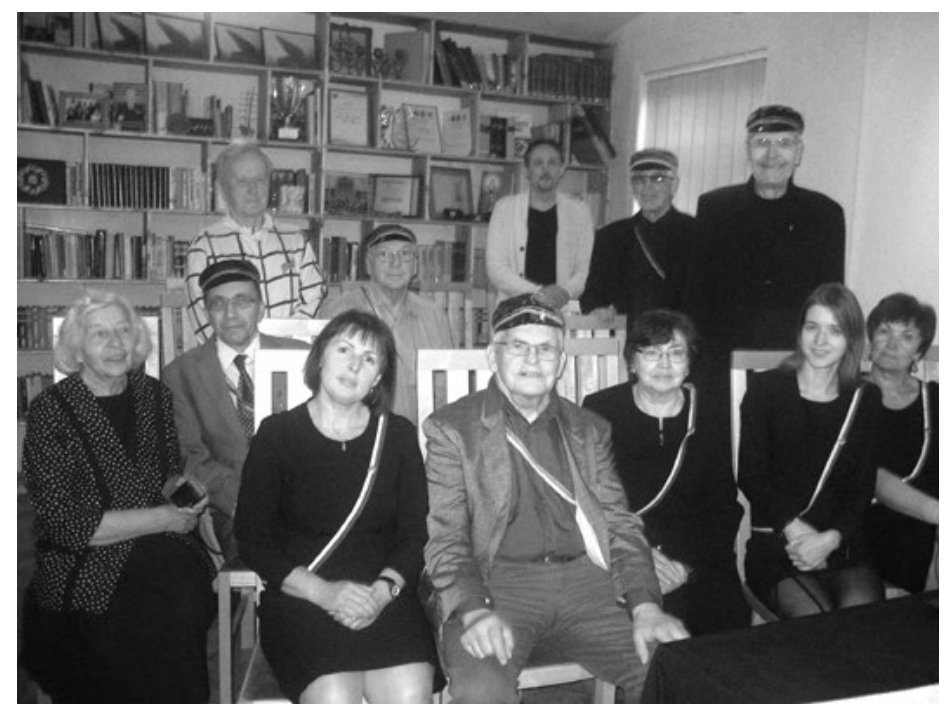

\section{4. attēls. Fr!R! literārais vakars kopā ar akadēmisko vienību Latviete}

Martuževa, Knuts Skujenieks, Ints Cālìtis un vēl simti citu Gulaga nometnēs. Bet arī pretoties, izliekoties piekrītam, bet cenšoties strādāt Latvijas un latviešu labā. Vismaz izdzīvot, saglabājot sapni par neatkarīgās Latvijas atdzimšanu un iedēstot šo sapni savu bērnu un mazbērnu sirdīs."

Fr!R! allaž bijusi nacionāli konservatīva organizācija, tāda tā ir arī savas simtgades priekšvakarā. Mēs augsti vērtējam Latvijas līdzdalību Eiropas Savienībā un NATO - šo integrācijas mērogu grūti pat salīdzināt ar vārgajiem reǵionālās integrācijas projektiem pirmajā Latvijas brīvvalsts laikā. Savā darbībā mēs rìkojamies

9 Berk̦is, Aivars; Hānbergs, Ēriks (2017). Ne tikai vagas vilcēji: Latvijas Zemnieku savienībai 100: 1917-2017. Rīga : Lauku Avīze, 95. saskaņā ar Rietumu civilizācijas vērtībām, strikti nosodot gan hitlerisko nacionālsociālismu pagātnē, gan totalitāro komunismu, kas aizvien vēl valda Kubā, Vjetnamā, Laosā un Ķīnas kontinentālajā daḷā. Taču mēs nesamierināsimies arī ar ultraliberālu globalizāciju, totālu komunitārisma aizstāšanu ar individuālismu, ${ }^{10}$ - un pašreizējā pandēmijas krīze tikai stiprina mūsu pārliecību, mudina smelt spēkus mūsu nācijas un visa Latvijas pilsoṇu kopuma (Latvijas tautas) kopējā veikumā.

Un mēs ticam, ka mūžu mūžos skanēs lepna dziesma brīvai Latvijai.

10 Sk. Pabriks, Artis (2009) Atbildība par brīvību. Akadēmiskā Dzīve, 46, 38-41. 